rhetoric. And I may be pardoned for concluding with a specimen of that rhetoric.

No one has better summarized the work of science and invention in the past century than Macaulay:

"It has lengthened life; it has mitigated pain; has extinguished diseases; has increased the fertility of the soil; given new security to the mariner; furnished new arms to the warrior; spanned great rivers and estuaries with bridges of form unknown to our fathers; it has guided the thunderbolt innocuously from heaven to earth; it has lighted up the night with splendor of the day; it has extended the range of human vision; it has multiplied the power of the human muscles; it has accelerated motion; it has annihilated distance; it has facilitated intercourse, correspondence, all friendly offices, all dispatch of business; it has enabled man to descend to the depths of the sea, to soar into the air, to penetrate securely into the noxious recesses of the earth; to traverse the land in cars which whirl along without horses; to cross the ocean in ships which run many knots an hour against the wind. These are but a part of its fruits, and of its first fruits, for it is a philosophy which never rests, which is never perfect. Its law is progress. A point which yesterday was invisible is its goal to-day, and will be its starting point tomorrow."

\section{PATENTS AND CHEMICAL INDUSTRY IN THE UNITED STATES. ${ }^{1}$}

By B. HERSTEIN.

Patents are intended to protect intellectual property in the industrial field. The close interrelation between patents and the development of modern industry is a stubject receiving sufficient consideration on the part of economists, so that in this place only those features need be dwelt on which characterize the specific relation of patents to the chemical industry and their economic bearing upon this industry in the United States as illustrated in the patent statistics of this country. A chemical patent differs essentially in one respect from all other patents in that the finished product in most instances does not carry any characteristic peculiar to the process used in this mantufacture, by which the latter could be identified and by which infringement could be established directly. This is the reason for the many secret and supposedly secret processes prevailing in many chemical establishments here and abroad, a condition which is only partially overcome in this country by the possibility of obtaining patent protection for the product itself if the same be new. Some manufacturers therefore prefer to take the inconvenience and risk resulting from the attempt to keep processes secret, a risk especially great in large establishments with a constantly fluctuating working force, rather than to make them even partially known to the interested public. Nevertheless, it may be said that, taken as a whole, the progress of industrial chemistry in recent years is recorded in the literature (patent) from the patent offices of the world, and

1 Paper presented at the joint meeting of the Am. Chem. Soc., Am, Electrochemical Soc., and the Soc. of Chem. Ind., New York, April 19, 1912. that in the number of inventions made and patented the chemical industry is not surpassed if indeed equaled by any other branch of manufacture.

This is true very largely also of the United States. In the careful and instructive study prepared by Story B. Ladd and published by the U. S. Census Bureau under the title "Patents in Relation to Manufacturers" ["Census of Manufacturers," 4, 776 (I902)] it is stated that up to the time of publication (I902) the following number of $U$. S. Patents had been issued in the principal branches of chemical manufacture:

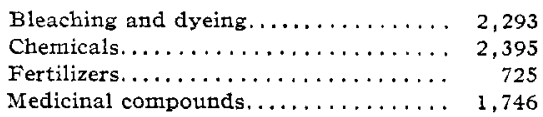

It will be seen that these patents do not cover all of the numerous branches of the chemical industry. The classification followed by the Patent Office devised to satisfy its special requirements, distributes chemical inventions over a wide range of divisions and subdivisions of which the principal ones can be seen from Table I. This table, which was prepared from the original files of the Patent Office, covers all the chemical inventions protected by $U$. S. Patents in the lines indicated for the decade rgoo-igro, but should not by any means be regarded as including those patents relating to the chemical industry which are classified under other divisions or subdivisions. The table further divides the patents issued during the decade according to the nationality of the patentee and the status of ownership at the time of issue, as far as the records go, showing whether the patents were still the individual property of the applicant or had already been assigned to other interests. The latter may, in some slight measure, be regarded as an indication of the immediate industrial applicability of the inventions, because in the majority of cases it denotes an invention made within an industrial establishment and for this reason possesses more chances of practicability and of being tried out in practice. This feature cannot readily be established in any other way.

The total number of patents issued in the United States between 1900 and I9 0 for the classes given in Table I was 4068, of which 3509 fell in Division VI, which embraces chemicals almost exclusively. By far the larger percentage, as is readily seen, covers inventions in organic chemistry, carbon dyes and carbon compounds alone furnishing I 547 patents, or 38 per cent. of the total number. The same percentage of the patents issued, namely 38 , and in absolute number 5552 , were taken out by Americans, the balance of $25 \mathrm{I} 6$ patents, or 62 per cent. of all patented inventions enumerated in the table, were obtained by inventors domiciled abroad. Of these 25 I 6 patents, German inventors took out the bulk, namely I 754, or 69.5 per cent., Swiss citizens coming next with 167 inventions, or 6.6 per cent. The following comparison is of interest: The total number of all patents issued in the United States between 1900 and r9I0 was 240,000-average per year 30,910of which those issued to foreigners domiciled abroad 
Table I.-Patents Relating to Principal Chemical Manufactures Taken OUt IN The Tnited States 2 during $1900-1910$, ACcording to NATIONAITY OF PATENTEE AND OWI

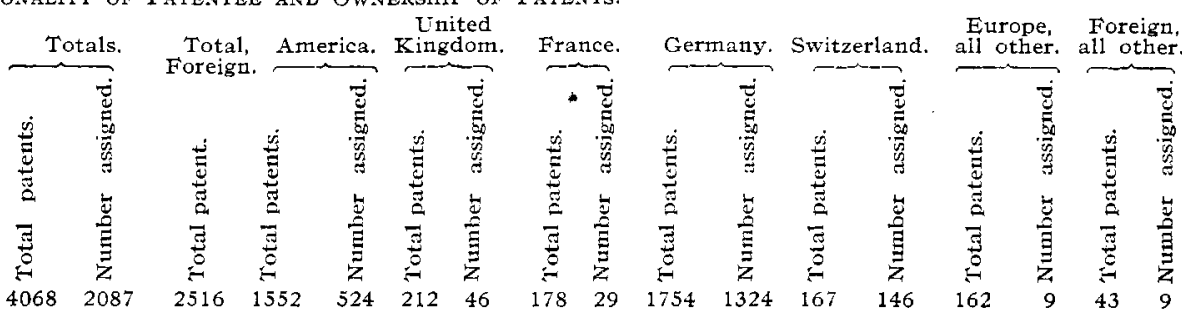

Grand totals...

DrvisIon III.

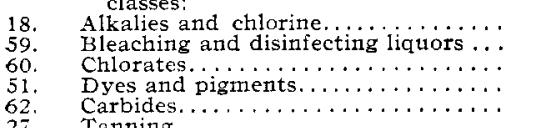

Tanning...

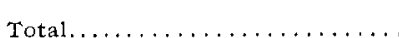

DIVIsion VI.

Class 8; Bleaching and dyeing: Sub.

classes:

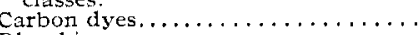

Bleaching.....

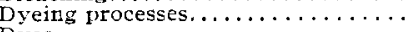

Mercerizing

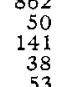

Yordants.

Total.

Class 23; Chemicals: Subclasses:

Melasses:

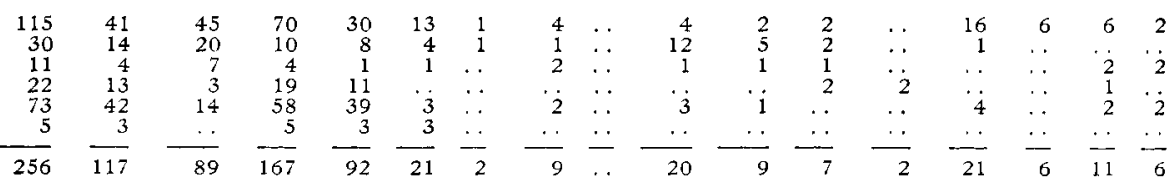

Fire-extingtiishing compounds.

Catalytic bodies. . . . . . . . . .

Metalloids............

Packing chemicals............

Apparatus.

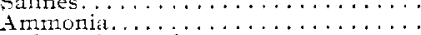

Soda and potash.....................

Carbon compounds.............. 42

rutal ................ $\overline{1517}$
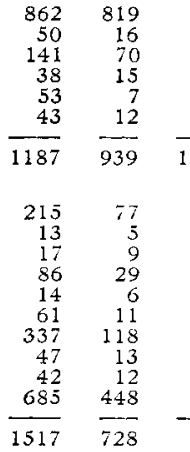

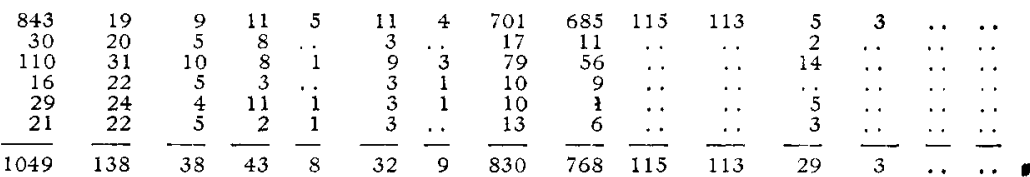

Class 52 ; Explosives: Subclass:

Nitro compontind............. $156 \quad 61$

Class 167; Medicines: Subclasses:

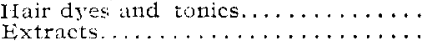

Extracts

Internal remedies. . . . . . . . . .

Topical renedies.

Insecticides. . . . . . . . . . . .

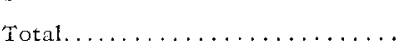

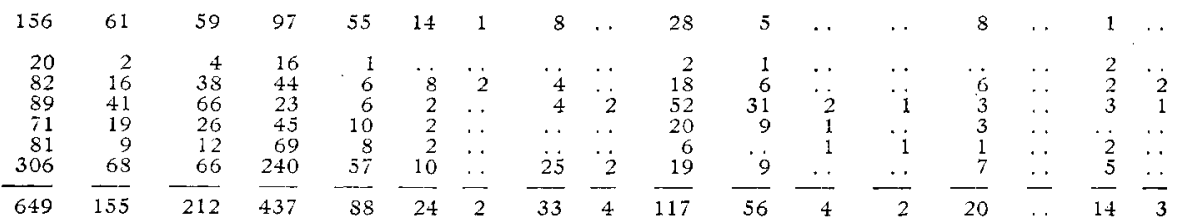

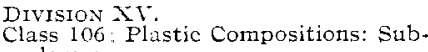

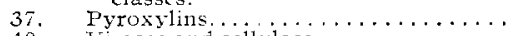

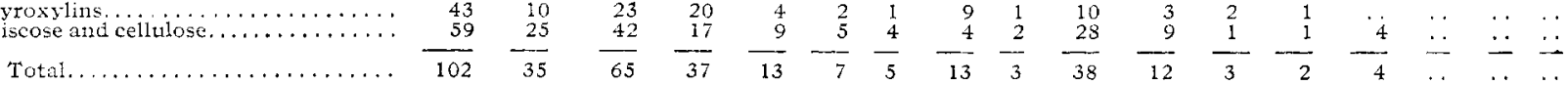

Class 18; Plastics: Subclass:

51. Pyroxylin.................. $14 \quad 10$

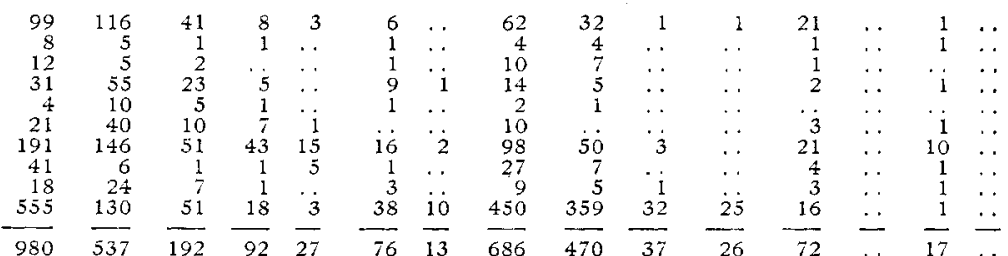

Division XXXI

Class 87 ; Oils, Fats and Glue: Subclass:

7 Class 134 . Liquid coating compositions: Subclasses:

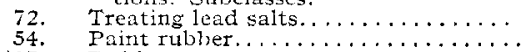
Rubber.......

Iron salts.

Lampblack.

Litramatine.

Zine salts...

Proxylin.

Class 203 ; Ammonia, water and wood

distillation: Subclasses...........

Ammonia, including turpentine......

4. Turpentine processes................

Tot I

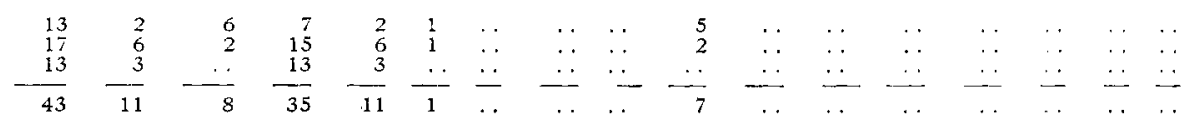


were 38,930 in number-average per year 3,540-or II. 4 per cent. In the chemical industry, according to Table I, the percentage of patents issued for inventions made and to patentees domiciled abroad was more than five times as great, namely 62 per cent.

Table II gives the average number of patents issued in the United States yearly during I900 and IgIo, average number and percentage quota of patents relating to chemicals only, granted according to nationality and domicile of patentees. Patentees of foreign birth residing in the United States, whether or not citizens of this country, are included among American patentees.

Table I1.--Average Number of Total and Chemical Patexts issued TO FOREIGNERS DURING 1900-1910.

\begin{tabular}{|c|c|c|c|}
\hline To citizens of & $\begin{array}{l}\text { Average number } \\
\text { of all patents } \\
\text { issued between } \\
1900 \text { and } 1910 .\end{array}$ & $\begin{array}{l}\text { Average } \\
\text { number of } \\
\text { chemical } \\
\text { patents. }\end{array}$ & $\begin{array}{l}\text { Percentage } \\
\text { of chemical } \\
\text { patents is- } \\
\text { sued to } \\
\text { citizens of }\end{array}$ \\
\hline United States...... & 27,375 & 155 & 0.5 \\
\hline Germany............ & 1,043 & 175 & 16.8 \\
\hline Great Britain. ......... & 900 & 21 & 2.3 \\
\hline France $\ldots . \ldots \ldots \ldots$ & 323 & 18 & 5.7 \\
\hline Switzerland. & 87 & 17 & 2.0 \\
\hline
\end{tabular}

The low percentage of chemical patents taken out by citizens of the United States is of course due to the great number of patents granted to American citizens in other industries and as such would be without any special significance, were it not for the fact that the absolute number of chemical patents taken out by citizens of the United States in their own country is considerably smaller than the number of patents issued in the U. S. to foreigners collectively and even smaller than the number of patents issued in the U. S. to Germans only. This preponderance of inventors residing abroad, especially German, in the chemical industry, applying for United States patents, has been pointed out already in the Census study referred to above (Loc. cit., p. 759), the result being as follows:

During the decade of I $890-1900$ there were granted in the United States 622 patents for "Carbon Dyes" and 3 I 2 patents for "Carbon Compounds," other than dyes. Of these, 609 , or 97.9 per cent., and 28 I, or 90 per cent., respectively, were issued to foreigners abroad, principally Germans. Table III, summarizing the salient features of Table I, shows that during the decade following this proportion had changed very little, if at all.

Table III.-Summary of Chemical Patents Issued IN the U. S. BetweeN 1900 and 1910. By Character of PAtent and Domicile of PatENTEE.

Patents for carbon compounds and bleaching and dyeing

All other

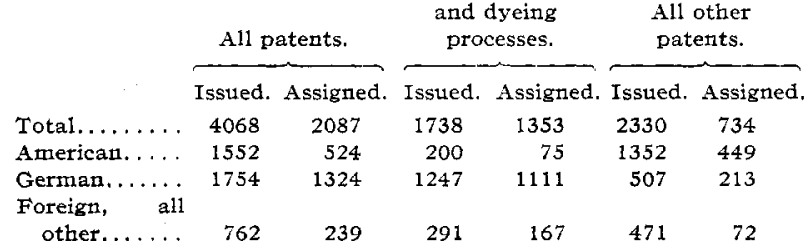

This table shows that the total number of patents issued during the period under consideration, $i, e$,
4068 , only 1552 , or 38 per cent., were taken out by resident Americans. Germans residing in Germany obtained I 754 patents, or over 43 per cent., and 762 patents, or little less than I 9 per cent., were issued to other foreigners residing abroad. In the groups, "Carbon Compounds, Bleaching and Dyeing Processes," I 738 patents were issued, of which only 200 , or II.5 per cent., were applied for by American citizens. This apparently indicates a slight progress against the preceding decade; yet such a condition must be admitted to be far from satisfactory considered from any point of view and least satisfactory when the material loss arising from such a situation is computed, since the groups mentioned constitute probably the most profitable branches of the chemical industry.

The statement has been made therefore that the fact that a patent was assigned prior to its issue is to some degree a measure of its immediate industrial utilization, and this is, for obvious reasons, even more true in the case of foreign applicants. The number of patent assignments given in Table I specifically for each country, and in a summary way in Table III, is therefore of some significance. Expressed in percentage for the whole of the field covered by this table they are as follows:

\begin{tabular}{|c|c|}
\hline Assignee residing in: & $\begin{array}{l}\text { Percentage of U. S. } \\
\text { chemical patents } \\
\text { assigned before issue }\end{array}$ \\
\hline & $\cdots \cdots \quad \begin{array}{c}38.8 \\
\text { Per cent. }\end{array}$ \\
\hline United Kingdom. . & 21.2 \\
\hline France............... & 16.3 \\
\hline Germany...$\ldots \ldots \ldots$ & $\ldots \ldots$ \\
\hline Switzerland. & $\ldots \quad 87.4$ \\
\hline
\end{tabular}

Patents issued to Swiss citizens cover almost exclusively Carbon Dyes and other carbon compounds, both industries being highly developed in that country and carried on by large corporations almost exclusively in the district of Basle. The proximity to Germany and a patent legislation-since changedwhich permitted the infringement of foreign patents, are largely responsible for the growth of these manufacturers in Switzerland.

Table III gives the number of all patents issued to Germans living in Germany during the period covered at I 754 , of which I 324 , or $75.5 \%$, were assigned before issue. The highest ratio of these assignments is reached in inventions relating to Carbon Dyes, namely 685 out of $80 \mathrm{I}$, or about 98 per cent. One additional point as brought out in this table deserves emphasis. Of the 1754 patents issued for German inventions, 1247 , or a little over 7 I per cent., related to carbon Dyes and compounds and bleaching and dyeing processes, in all only 5 subdivisions out of more than 40 accounted for in Table I. The number of the assigned inventions was IIII out of I247, or practically $9 \circ$ per cent, and of these, as is shown in Table IV, 844 inventions, or 68 per cent., were assigned to only four companies, who in connection with one other company by an interchange of stock and division of profits under an agreement to last 50 years from I904, work on a "community of interest" plan, as revealed by their own reports. ( $H$. 
Schultze, Entwicklung der chem. Industrie, Halle, r9o8, p. 786.$)$

Takle IV.-American Patexts Assigned to Specific German ComPANIES, BETWEEN 1900 AND 1910. Bleaching and Carbon dyeing Carbon Name of company. pounds. cesses. Carbon

Aktiengesellschaft für Farben, Berlin...............

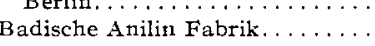

Bayer \& Co., Farbenfabrik, Elberfeld................ 104

Meister Lucius \& Bruening ..... .

Total............... 205

Total patents issued to Germans. 450

\begin{tabular}{r}
9 \\
34 \\
104 \\
58 \\
\hline 205 \\
450
\end{tabular}

\begin{tabular}{rr}
1 & 48 \\
34 & 188 \\
& \\
19 & 217 \\
\hline 7 & 115 \\
\hline 71 & 568 \\
96 & 701
\end{tabular}

Total.

$48 \quad 58$

58
256

340

190

844

1247

A patent is essentially a monopoly, maintained with the consent and enforced with the help of the government. Its prime object and recognized social value consists in promoting the material development. of industry in the country of issue. Viewed from this point, it seems that the development of the chemical industry in the United States has not kept pace with the number of patents issued. Our patent laws are stringent as to novelty and lenient to the inventor or his assignees. These practically certify the first and give far-reaching protection to the latter-much more protection than in any other country-because the American law recognizes the patentability of the product as such, so that no other process or improvement thereof can touch it during the life of the patent in the United States except with the consent of the original inventor or his assignees.

This feature permitting a product patent and specific only of the American patent law presents a serious problem especially in its relation to the chemical industry. In this industry the product is of paramount importance. The process by which a given product is obtained is not absolutely characteristic thereof, because the same product may be obtained in different ways, varying only little or none at all in the degree of commercial feasibility. But it is self-evident that under the American law the owner of a product patent can prevent the manufacturer of this product by others, even if their process were entirely new and not merely an improvement on the original process, and though this new process were preferable materially, or otherwise offered inducements for its adoption. In the end, such a policy works against industrial progress or against the basic purpose of all patent legislation.

The liberal intention of the law to give the original inventor as much opportunity as possible to derive material benefit from his invention may be considered commendable if the interests of the inventor were the sole factor to be looked after. This, however, is not the case. A patent is a contract between the patentee and society-at-large, a quid pro quo, in which the interests of the state are entitled to at least equal consideration with those of the inventor. It is a debatable question whether these interests are sufficiently protected where an individual, single or corporate, possesses legal power to prevent the utiliza-

tion of improved manufacturing processes as applied to specific products covered by patents.

In the earlier times of our industrial development, such a provision of law may have had its justification. Inventions were then largely due to the efforts of single individuals working along certain lines with little fear of interference. The inventions wanted in complexity, their value could be more easily appreciated, the utilization was more immediate, the result more direct. The progress of science and the interdependence of its several branches have changed these conditions entirely. Only in rare instances can one single man overlook the entire field of work in which he is engaged. The personal element, previously so large a factor, has gradually been eliminated to a great extent and the noteworthy achievements of to-day in science, and in industry as well, are the results of many brains focused upon the same object, sometimes working together, of ten working independently, but always influencing one another. It is the collective product of the mass and not the individual product of the unit. In no branch of industrial and scientific activity perhaps is this principle of coopperation better illustrated than in chemistry and nowhere has it been accompanied by more beneficent results for society-at-large. The industrial and scientific progress of chemistry is to-day carried on in huge establishments by any army of workers each contributing his share towards the whole. This results daily in the discovery of many new products, some of inmediate, others of potential commercial value, and for this reason the practice of protecting all new discoveries by patents has become universal. But in most industrial countries, the patent protects the process only and for their own protection the inventor and his assignees are therefore compelled to experiment in all possible directions that may conceivably lead to the same product in order to insure for themselves the reward coming from its manufacture. If, on the other hand, the material reward arising from a certain specific chemical manufacture be sufficiently large, competitors will be drawn to it and these will bend their energies toward devising new processes in order to be able to take up this manufacture without infringing upon existing patents. The result is doubly beneficent, not only because it stimulates legitimate rivalry, but more so perhaps because work along such lines is bound to lead to discoveries often entirely unforeseen and pre-eminently useful. But where the patent covers the product, irrespective of the process for its manufacture as in the U. S., the tendency will be, for obvious reasons, toward stagnation. This feature is borne out statistically, though, of course, only in a very inconclusive way, for want of adequate data, as follows:

Table IV shows that the four German companies there mentioned had secured on an average about 80 patents per year in the United States. These same four companies have taken out in 1907 , which if anything was rather an off-year in Germany, $18 \mathrm{x}$ patents. (James Baron, "Chemical Industries on the Continent," I909). 
There is yet another important feature to the U. S. patent laws, not found in most other industrial countries, which in the opinion of competent observers is not calculated to promote industry and by which the chemical industries especially, owing to their pectiliar nature, are negatively affected.

Contrary to the requirements of the patent laws of most other industrial countries, the Unites States does not specify compulsory working of the patent issued, but permits the patentee, and him only, to import his products into the United States from whatever place he chooses, giving him a monopoly of the market without imposing upon him any obligation or demanding of him any equivalent except the minimum fee paid originally to the Patent Office. In the case of the American inventor such a situation will develop only under exceptional circumstances; with the foreigner, however, it is for obvious reasons the rule, in the chemical industry especially. The American market is the most valuable in the world and the foreign inventor or his foreign assignees naturally take all the advantage that the law gives them to exploit this market as profitably as they can. This very largely accounts for the tardiness with which the chemical industry develops in the United States, especially in those branches which depend preponderatingly upon inventions and therefore cannot be gaged by any tariff legislation under the theory of cost equalization or under any other theory.

Up to I 907 the English patent laws did not require compulsory working in England of patents issued there, but the situation became so unbearable that the law was changed and the compulsory working feature established with the result that, according to a report in the London Times (March 23, I 9 I I) up to I9I I 50 foreign firms had begun, or were about to begin, manufacturing in England, involving an investment of about $\$ 4,000,000$ and the employment of nearly 7,000 wage earners, with a weekly pay roll of $\$ 40,000$. This did not include the large number of licenses granted by the patentees to English manufacturers under the best conditions obtainable, choosing this alternative rather than suffer the threatened repeal of the patent. German and American interests were particularly affected by this change in the law and the manufactures introduced were those of filaments for electric lamps, photographic films especially for the cinematograph, anilin dyes, medicines, glazes, oxygen, etc., all practically chemical manufactures, besides processes for making mercerized cotton, and food products (which are related chemical industries).

With reference to France, it has been stated on good authority that many firms engaged in the chemical industry in that country are controlled by foreigners, and this also is largely due to the compulsory working feature of the French patent laws. Germany imposes the same obligation, though it is waived in favor of American patentees. In the United States, practically single in this respect among the industrial nations of the world, the progress of the chemical industry as reflected by the patents issued must be traced not by the broadening of the domestic production but in the imports only.

What has been said above is to be considered as an attempt to point out anew those fundamental characteristics of our patent legislation which, in their bearing upon the chemical industry at least, are calculated to retard rather than to promote the development of manufactures in the United States. It must be recognized that chemical manufactures are but a small, even if a very important part of our industrial structure. Expressed in the number of patents taken out, the figures quoted before show that scarcely more than one per cent. of patents issued cover inventions properly called chemical. Thus, even if admitting that this small percentage is in a large measure the result of a retarded development and should therefore the readier call for corrective, it is obvious that from the viewpoint of national economy no legislative remedial measures may be expected unless it can be demonstrated that the interests affected adversely are considerably greater than indicated, or that correction can be applied without prejudice to the many other complex questions involved.

As American chemists, however, working in the United States, and virtually affected by the status of the chemical industry here, we are preèminently interested, and it is our duty to see that the proper conditions for the natural development of our industry be maintained and all barriers affecting it negatively be removed. No one at all acquainted with the subject will deny, and a study of the foreign trade statistics will immediately show, that the building up of the chemical industry in this country has been extremely one-sided. The manufacture of heavy chemicals, on the one hand, is in most respects on an equality with the best anywhere, and the same is true of the staple organic and medicinal chemicals. The manufacture of so-called fine chemicals, however, and especially of coal tar and coal tar products, is sorely inadequate, retarded or even dwarfed if you will. And this is not for want of raw materials or other primary elements essential for the existence of such manufactures, but more so because both tariff and patent legislation have created a situation forcing enterprise in one direction and preventing it becoming engaged in the other. Unlike the heavy chemical industry, the manufacture of fine chemicals and of coal tar products derives its profitableness exclusively from patents. The greatest material gain comes during the life of the patent, owing to the monopolistic character of the latter, and naturally the profit is not lessened or otherwise interfered with however high the duty may be put, so long as domestic production is made impossible and imports are permitted, as is the case in the U.S. Here, if anywhere, the consumer pays the full duty. After the patent has expired the specific product may have gone largely or entirely out of use, or the owner of the patent will have gained so much experience that he can lessen very materially the cost of production and consequently also the selling price without affecting much the rate of profit, or he will have developed 
some new manufactures along the same line, obtain patent protection for them and the profit from these will be sufficient to compensate him for the diminished sales and profits on the original product. Competitors who take up the manufacture of articles, patents on which are about to expire, expect to live, so to speak, on the gleanings left on the field after a rich harvest. In the United States, with reference to chemical manufactures especially, the government is expected to equalize by tariff legislation conditions which have become unequal in time and the economic handicap cannot, therefore, be eliminated without putting serious burdens directly or indirectly on the consumer.

That industries can be legitimately and should be deliberately promoted by judicious tariff legislation is not open to much controversy in this country, but tariff legislation is but one out of the many factors influencing our enormously complex industrial life, and as far at least as chemical manufactures are concerned, judicious patent legislation is undoubtedly of equal importance with the former. It was the purpose of this paper to point out and to emphasize this importance, and the extent to which this has been accomplished will express the degree of justification for its having been presented before this society.

\section{THE ABUSES OF OUR PATENT SYSTEM. ${ }^{1}$}

By L. H. BAEKELAND.

Received April 10 41912 .

A recent decision of the Supreme Court (Sidney Henry, et. al., vs. A. B. Dick Co., March Ir, Igr 2. No. 20, October Term, I9II) upholding the right of patentees to dictate under what conditions a patented article shall be sold, or shall be licensed, has become the object of much criticism. One of our newspapers repeats the comment, that this decision could be interpreted to its extreme limits so as to mean that "it would enable the patentee of a window frame to dictate that all the material of a house in which the frame was to be used must be procured by him." But that argument overlooks the fact that nobody is compelled to buy that particular patented window and that the public-at-large can purchase any other window frame not patented, or of which the possession is not submitted to any restrictions. The Supreme Court decision simply means that the owner of a patent, in selling or licensing under it, has the same privileges that the owner of any other private property has. For instance, the proprietor of a lot can sell it with the restriction that if any house is to be built on it, the materials for this building shall be purchased from him. It all depends whether the purchaser is willing to submit to these terms or prefers to forego acquisition under such restrictions. To assail this decision of the Supreme Court, is to deny the elementary rights of private property, or to deny that a patent is private property.

Justice Lurton, in expressing the majority opinion of the Supreme Court, very correctly says: "When the patent expires, the public will be free to use the invention without compensation or restriction."

"Paper presented at the joint meeting of the Am. Chem. Soc., Am. Electrochem. Soc, and the Soc. of Chem. Ind.. New York, April 19, 1912.
Outside of this limitation, why should restrictions be put upon ownership of patents, which do not exist for other forms of private property? An invention is the creation of something which did not exist before. Is the creator of this invention not entitled to undisturbed ownership, at least for a short period of $\mathrm{r} 7$ years, when the ownership of real estate, or other private property is undisturbed and continues forever?

And yet, real estate always existed long before it got in the hands of private owners. Its mere possession does not imply any special merit, nor does the private ownership of real estate confer any benefit upon the community. Nevertheless, real estate can be left idle at the whim of the owner, who in the meantime benefits by the enhanced value, the unearned increment, conferred upon his property through the enterprise of the community at large, and more especially by the enterprise of his immediate neighbors, who take the trouble and the risk to develop their own real estate, while he just remains inactive.

So that, in this and many other ways, the owner of real estate, or other private property, has an incomparably greater scope of unquestioned property rights than a patentee. Furthermore, these rights do not cease after 17 years, but continue forever.

It is a significant fact that in many cases, the persons who object most to patent rights are just those who have lived in surroundings where industrial or intellectual development is least apparent.

In some parts of the country, the word "patent" is scarcely known, and the conception of a higher class of property than that which is merely acquired by inheritance or money purchase is difficult to understand. $\mathrm{O}_{n}$ the other hand, the conception of intellectual property rights is one of the symptoms of a higher state of civilization.

I may point out on this occasion that the little state of Connecticut takes out more patents than all the Southern states together.

Most people imagine that patent laws are for the exclusive benefit of inventors, and this regrettable mistake leads to many misunderstandings. Were this opinion correct, patent laws would mean class legislation, and would be as unfair, as undemocratic, as unwholesome, and as dangerous as any other class legislation.

But the patent laws, as framed under the Constitution of the United States, are primarily conceived for the benefit of the nation. No country has benefited more by its patent system than the United States. Compare the tremendous industrial development of such nations which have liberal patent laws, like the United States, Germany and England, with that of the Latin countries, where patent laws are less favorable to the inventor.

There is one civilized country, Holland, which until recently had no patent law whatever, and allowed the unrestricted use of any invention. This ought to have been the Paradise of Infringers; it was easy enough to use freely in Holland processes patented in other countries, and to distribute from there, infringing goods to all the countries of the world. Yet what 